\title{
Threat Analysis and Proposed Solutions for Elekdag Wildlife Development Area
}

\author{
Ömer Küçük, Kerim Güney, Özkan Evcin, Emre Aktürk
}

Kastamonu University, Faculty of Forestry, Kastamonu, TURKEY.

\begin{abstract}
Natural Wildlife Development Area is a protection status declared in accordance with the Land Hunting Act No. 4915. Within this scope, there are 80 Wildlife Development Areas in our country. The aim of this study was to observe possible threats in the Elekdag wildlife development area and to suggest solutionsfor the area. Elekdag Wildlife Development Area is located in Kastamonu province within the boundaries of Tasköprü county. The administrative responsibility of Elekdag Wildlife Development Area belongs to the General Directorate of National Parks and Nature Conservation, which is affiliated to the Ministry of Environment and Forestry, Kastamonu Provincial Environment and Forestry Directorate. As a result of the study, it was found that the wildlife habitats for deer populations (target species) and water resources in the area at risk. The identification of the risks on habitats and biological resources and proposed solutions have great importance on ecosystem integrity of the protected area. Therefore, we proposed some solutions to eliminate these risks. The most important factor is the arranging on-site management to ensure sustainable protection-use balance.
\end{abstract}

Key words: Threat Analysis, Wildlife Development Area, Wildlife, Conservation, Biodiversity, Elekdag, Kastamonu.

\section{INTRODUCTION}

Wildlife is a term which includes animal species, fungi, plants and other organisms living in the wild without human influence on an ecosystem. Therefore, protection, planning and development of wildlife are required to be evaluated with all components of the ecosystem. ${ }^{1}$

Wildlife populations are rapidly decreasing day by day. The purpose of harvesting natural resources for industry production and urbanization by human activities, causing the habitat destruction. ${ }^{2}$ Particularly, the destruction has increased in the last 200 years. As a result of this, many animals have become extinct or endangered. ${ }^{3-22}$ Land and marine mammals are the most common endangered species in the extinction status which has been formally evaluated in the International Union for Conservation of Nature (IUCN) red list. ${ }^{4-5}$ Governments and non-governmental organizations have been developed rules, regulations and strategies in order to conserve natural resources. ${ }^{5}$ Therefore, wildlife management organizations play an important role by securing a future for nature conservation and wildlife. In addition to that, human activities pose significant threat to population level, destruction and degradation of wildlife and its habitat. ${ }^{6-23-26}$

Many protected area have been declared for sustainable biodiversity and environment in all over the world. The Anatolia is one of the most important regions of the world in terms of fauna and many endemic species, have been the scene of various civilizations for thousands of years. Turkey is located at three different plant geographical regions (Euro-Siberian, Mediterranean and Iran-Turan) as a bridge and junction point in terms of biodiversity as well as historical and social aspects. ${ }^{7,8}$ Turkey thus has a great wealth in both fauna and flora. Turkey
DOI: 10.5530/ijper.51.3s.56 Correspondence: Ömer Küçük, Kastamonu University, Faculty of Forestry, Kastamonu, TURKEY 37150 Phone no: +905425803858 / +903662801702

E-mail: omerkucuk@kastamonu.edu.tr

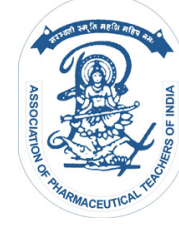

www.ijper.org 
is also a home to three of 37 different flora regions of the World being a meeting point of different plant geographies is the increasing the importance of this botanic wealth. ${ }^{5}$

Important nature areas of Turkey due to biological diversity are generally protected by different protection statues. Some of these protection statues are based on the national legislation and some of them are based on international contracts. Today, there are many protected areas (e.g. National parks, nature parks, wildlife development areas and etc.) with different types of management carried out by seperated institutions in Turkey. The game and wildlife in Turkey is being managed by General Directorate of Nature Conservation and National Parks under the Ministry of Forestry and Water Affairs. The Turkish Constitution, laws, regulations, and international conventions such as Paris, Ramsar, Bern, Washington (CITES), Barcelona, Combatting Desertification, and Biological Diversity provide the legal framework for nature conservation, sustainable resource use and management. The Forest Law coded 6831 enacted in 1956, National Parks Law coded 2873 enacted in 1983, and Land Hunting Law coded 4915 enacted in 2003 authorizes Ministry of Forestry and Water Affairs for conservation, improvement, and sustainable management of forests, wildlife resources, and biodiversity. ${ }^{9}$ Wildlife Development Area is a protection status declared in accordance with the Land Hunting Act No. 4915 in Turkey. According to this law, Wildlife Development Area is defined as "Fields in which hunting and wildlife are protected, developed, game animals are placed, measures are taken to improve the living environment, and hunting can be carried out within the framework of special hunting plan if necessary". ${ }^{10}$ In Turkey, there are 81 Wildlife Development Areas. ${ }^{11}$ Kastamonu is a home to 4 of 81 Wildlife Development Areas (WDA) in Turkey with a position to enclose the elements of the Euro-Siberian phyto-geographical region and rich diversity in terms of flora and fauna. ${ }^{12}$ Management plans for the areas which is important for wildlife, and threat analysis for sustainable management are filling a crucial gap for the management plans. Therefore, this is one the first study showing threat analysis for wildlife development areas in Turkey. Our study defines potential threats for Elekdag wildlife development area which is located in Kastamonu.

\section{MATERIALS AND METHODS}

Study Area: Elekdag Wildlife Development Area is located in Kastamonu province and within the bounda- ries of the Taşköprü district. The total area is 4236 ha and the altitude ranges from 830 to $1515 \mathrm{~m}$. Average slope of the study area was about $40 \%$. The climate can be characterized as the transition zone between West Black Sea Region and Central Anatolia Region. The administrative responsibility of Elekdag Wildlife Development Area is under the General Directorate of National Parks and Nature Conservation. ${ }^{13}$

Elekdağ is hosting 24 tree taxon, 19 bush and, 171 herbaceous plants taxon. Total 214 taxon of 19 are endemic. Also the area is hosting 18 mammal species. Target species of the area is Red Deer (Cervus elaphus). ${ }^{13}$

\section{METHODS}

Inventories based on direct observations i.e. data collection from floral and faunal elements in Elekdag. Furthermore, we review literature done in the area, used previous inventories done by the Ministry of Forestry and Water Affairs, X. Regional Directorate. ${ }^{13,14,15,16,17}$ Face to face interview were done with the local people to estimate the possible threats in the area.

Threat analyze was made in during 2015-2016 period. Overall, Threat Rank method were used to make proposals to Elekdag WDA. ${ }^{18,19,20}$

To determine the threats:

- Anthropogenic factors affecting the area were investigated (e.g. land use, grazing, illegal hunting, fires and mine activities).

- Values of resources ( e.g. flora, fauna andfood reserves) for wildlife development area were estimated and ranked,

- Habitat surveys were done for aim species (Cervus elaphus) of the area.

- Monitoring of wildlife were done during the season of study.

Zoning of Kastamonu Elekdag WDA due to the classification of protection was done after the threat analyze.

\section{RESULTS}

Threat ranking based on average threat scores, main protection targets, in order of declining importance, were: 1 - protection of deer populations and habitats, 2- conservation of mixed forests, 3- preservation of water resource (Table 1).

Zoning is very important in order to maintain the sustainable management in Wildlife areas. Due to data obtained from Elekdag WDA, percentage of the zones were given in Table 2 . 
Table 1: Definitions of threats used in the Elekdag threat assessment

\begin{tabular}{|c|c|c|}
\hline \multicolumn{3}{|c|}{ Aim of Protection : Conserving deer populations and their habitats } \\
\hline \multicolumn{3}{|c|}{ Pressure : Decreasing population } \\
\hline \multicolumn{3}{|c|}{ Source of Pressure } \\
\hline $\begin{array}{l}\text { 1. Inadequate awareness of biodiversity, } \\
\text { forests and wildlife protection and lack of } \\
\text { education }\end{array}$ & 2. Poaching by the local people & 3. Old fashioned forest management plans \\
\hline 4. Wild dogs & $\begin{array}{l}\text { 5. Unauthorized and unplanned cattle } \\
\text { grazing in forested areas }\end{array}$ & 6. Habitat degradation \\
\hline \multicolumn{3}{|c|}{ Proposals } \\
\hline 1.Education and awareness-raising & $\begin{array}{l}\text { 2.Preparing social activities (paintball, } \\
\text { nature photographing, trekking etc.) for } \\
\text { reducing the pressure }\end{array}$ & $\begin{array}{l}\text { 3.Raising the protection of village legal } \\
\text { entities to } 12 \text { months }\end{array}$ \\
\hline 4.Building a systematic conservation plan & $\begin{array}{l}\text { 5.Preparing the plan due to Ecosystem } \\
\text { Based and Multi-Purpose Planning } \\
\text { Technique }\end{array}$ & $\begin{array}{l}\text { 6. Raising awareness of interest groups } \\
\text { about nature love and protection }\end{array}$ \\
\hline $\begin{array}{l}\text { 7.Planning the production of non-wood } \\
\text { forest products }\end{array}$ & $\begin{array}{l}\text { 8.Creation of predatory and habitat } \\
\text { monitoring programs }\end{array}$ & $\begin{array}{l}\text { 9.Consideration of new investments in the } \\
\text { region of the animal's habitat and migration } \\
\text { path }\end{array}$ \\
\hline $\begin{array}{l}\text { 10.Revealing ecological effects of water } \\
\text { sources }\end{array}$ & 11.Building a sustainable hunting plan & $\begin{array}{l}\text { 12.Promoting implementation of appropriate } \\
\text { ecotourism }\end{array}$ \\
\hline \multicolumn{3}{|c|}{ Aim of Protection : Preserving Pure Coniferous and Mixed Confierous Forests } \\
\hline \multicolumn{3}{|c|}{ Pressure : Effects of humans and animals } \\
\hline \multicolumn{3}{|c|}{ Source of Pressure } \\
\hline 1. Forest villager's firewood needs & $\begin{array}{l}\text { 2. Inadequate awareness of biodiversity, } \\
\text { protection of forests and lack of education }\end{array}$ & 3. Old fashioned forest management plans \\
\hline $\begin{array}{l}\text { 4. Unauthorized and unplanned cattle } \\
\text { grazing in forested areas }\end{array}$ & 5. Habitat degradation & \\
\hline \multicolumn{3}{|c|}{ Proposals } \\
\hline 6. Education and awareness-raising & 7. Building a systematic conservation plan & $\begin{array}{l}\text { 8. Preparing the plan due to Ecosystem } \\
\text { Based and Multi-Purpose Planning } \\
\text { Technique }\end{array}$ \\
\hline $\begin{array}{l}\text { 9. Raising awareness of interest groups } \\
\text { about nature love and protection }\end{array}$ & $\begin{array}{l}\text { 10. Planning the production of non-wood } \\
\text { forest products }\end{array}$ & 11. Building a sustainable grazing plan \\
\hline $\begin{array}{l}\text { 12. Promoting implementation of } \\
\text { appropriate ecotourism }\end{array}$ & 13. Encourage the alternative livelihoods. & \\
\hline \multicolumn{3}{|c|}{ Aim of Protection : Preservation of water resources } \\
\hline \multicolumn{3}{|c|}{ Pressure : Intensive and unplanned consumption of natural spring waters, Contamination of water resources, Erosion } \\
\hline \multicolumn{3}{|c|}{ Source of Pressure } \\
\hline $\begin{array}{l}\text { Inadequate awareness of biodiversity, lack } \\
\text { of education }\end{array}$ & Unconscious water use of local people & Using pesticides and fertilizer \\
\hline \multicolumn{3}{|c|}{ Proposals } \\
\hline $\begin{array}{l}\text { Raising awareness of the interest groups } \\
\text { about the importance of water }\end{array}$ & $\begin{array}{l}\text { Education in schools about global warming } \\
\text { and water }\end{array}$ & Regulating water use \\
\hline $\begin{array}{l}\text { Monitoring the pollution of the water } \\
\text { resources in the area }\end{array}$ & $\begin{array}{l}\text { Encouraging the use of ecological } \\
\text { agriculture and modern irrigation techniques }\end{array}$ & \\
\hline
\end{tabular}




\begin{tabular}{|c|c|c|}
\hline \multicolumn{3}{|c|}{ Table 2: Zone percentages of Kastamonu Elekdag WDA } \\
\hline ZONE OF ELEKDAĞ WDA & Acreage( ${ }^{\text {(ha) }}$ & Total percentage of area(\%) \\
\hline Absolute Conservation Zone & 0 & 0 \\
\hline Strict Protected Area & 2900.82 & 68.48 \\
\hline Sustainable Use Area & $890, .62$ & 21.02 \\
\hline Controlled Use Zone & 444.89 & 10.50 \\
\hline TOTAL & 4236.33 & 100 \\
\hline
\end{tabular}

\section{CONCLUSION}

Lack of knowledge and non- awareness about conserving wildlife habitats regarding the nature of threats were found the major threat for the area. $68 \%, 48$ of WDA is considered as Strict protected area. The results of zoning shows that majority of the area is potencially under risk of habitat destruction. In addition to understanding complex ecological systems, removing the threats, resource use, agriculture, water diversion, and construction, often requires understanding and addressing interrelated economic and social factors. ${ }^{21}$

Although fact that most of the forest management plans are made with Ecosystem based and Multi-Purpose Planning Technique, biological diversity is not completely reflected in the plans. For this reason, the basic forestry practices are still being implemented. This situation has significant risks on biodiversity.

The red deer (Cervus elaphus) has a good population in suitable habitat areas. The protection of these species is crucial for a healthy continuation of wildlife and sustainability. In addition, there are also important clean water sources on the field. The identification of the threats and pressures on these resources, and also identification of strategies and actions to address these pressures and threats are important in the management of protected areas. ${ }^{25}$

\section{ACKNOWLEDGEMENT}

This study was supported by Kastamonu University Scientific Project Department with project code KU-BAP03/2015-6.

\section{CONFLICT OF INTEREST}

None

\section{ABBREVIATION USED}

WDA : Wildlife Development Area; IUCN: International Union for Conservation of Nature; CITES:
Convention on the International Trade in Endangered Species of Wild Flora and Fauna.

\section{REFERENCES}

1. Evcin Ö, Küçük Ö, Akkuzu E, Ugış A. Habitat preferences of roe deer (Capreolus capreolus) in Kastamonu: case study of Elekdağı wildlife development area. IJESRT 2017;6(4):225-29.

2. Sahney S, Benton MJ, Falcon-Lang HJ. Rainforest collapse triggered carboniferous tetrapod diversification in Euramerica. Geology 2010;38(12):1079-82.

3. Young People's Trust for the Environment, [homepage on the Internet], Endangered Animals of The World [updated 2016 Jun 15; cited 2017 Jun 22]. Available from: https://ypte.org.uk/factsheets/endangered-animals-of-the-world/ habitat-destruction\#section

4. The International Union for Conservation of Nature [database on the Internet]. IUCN Red list [updated 2017 Jun 22; cited 2017 Jun 22]. Available from: http://www.iucnredlist.org/

5. Guloglu, Y. National and international conservation of biological diversity in terms of administrative law "Sample of Turkey". Finland: InTech; 2017 [cited 2017 Jun 22]. Available from: https://www.intechopen.com/books/geneticdiversity

6. Akkuzu E, Ünal S, Evcin, Ö. Wildlife education in higher education institutions, its importance and encountered problems. Turkish Journal of Forestry. 2015;16(1):82-85.

7. Kaya Z, Raynal DJ. Biodiversity and conservation of Turkish forests. Biol. Conservation. 2001,97(2):131-41.

8. Kahraman A, Önder M, Ceyhan E. Biodiversity and biosecurity in Turkey. International Conference on Biology, Environment and Chemistry; 2011 Dec 28-30; Dubai, United Arab Emirates. Singapore: IACSIT Press, 2011. p. 33-37.

9. Republic of Turkey Ministry of Foresty and Water Affairs General Directorate of Nature Conservation and National Parks [homepage on the Internet], Game and Wildlife in Turkey [updated 2013 Jan 1; cited 2017 Jun 22]. Available from: http://www.milliparklar.gov.tr/kitap/77/AV_YABAN_ING.pdf

10. Hunting Law Act, Pub. L. No. 4915, Ministry of Forestry and Water Management (2003).

11. Republic of Turkey Ministry of Foresty and Water Affairs General Directorate of Nature Conservation and National Parks [homepage on the Internet], Wildlife Development Areas [updated 2017 Jun 1; cited 2017 Jun 22]. Available from:http://www.milliparklar.gov.tr/

12. Ugış A, Akkuzu E, Evcin Ö. Aquatic birds of Beyler and Karaçomak Dam Lake in Kastamonu province. Journal of Kastamonu University Journal of Forestry Faculty. 2015;16(2):447-62.

13. Republic of Turkey Ministry of Foresty and Water Affairs General Directorate of Nature Conservation and National Parks, Elekdağ Wildlife Development Area Management and Development Plan, 2015. Kastamonu (Turkey).

14. Evcin Ö. Roe deer (Capreolus capreolus) distribution of Kastamonu and determination of living areas [dissertation]. Science and Technology Institute: Kastamonu University; 2013.

15. Republic of Turkey Ministry of Foresty and Water Affairs General Directorate of Nature Conservation and National Parks, Elekdağ Wildlife Development Area Management and Development Plan, 2012. Kastamonu (Turkey). 
16. Republic of Turkey Ministry of Foresty and Water Affairs General Directorate of Nature Conservation and National Parks, Elekdağ Wildlife Development Area Management and Development Plan, 2009. Kastamonu (Turkey).

17. Republic of Turkey Ministry of Foresty and Water Affairs General Directorate of Nature Conservation and National Parks, Elekdağ Wildlife Development Area Management and Development Plan, 2008. Kastamonu (Turkey).

18. New Hampshire Fish and Game [homepage on the Internet], 2015 Threat Assessment Instructions For Ranking Threats to Species and Habitats, [updated 2015 Jun 1; cited 2017 Jun 22]. Available from: http://www.wildlife. state.nh.us/wildlife/documents/wap/appendixe-threatrankinstructions.pdf

19. The Urban Wildlands Group [homepage on the Internet], Lange's metalmark butterfly threat assessment and ranking of potential management alternatives: final report, [updated 2015 Apr 1; cited 2017 Jun 22]. Available from: http:// www.urbanwildlands.org/Resources/2015_LMB_Report_FINAL.pdf

20. OWASP [homepage on the Internet], Application Threat Modeling, [updated 2017 May 31; cited 2017 Jun 22]. Available from: https://www.owasp.org/ index.php/Application_Threat_Modeling
21. Lawler JJ, Campbell SP, Guerry AD, Kolozsvary MB, O'Connor RJ, Seward LC. The scope and treatment of threats in endangered species recovery plans. Ecol. Appl.2012;12(3):663-67.

22. Isah T. Rethinking Ginkgo biloba L.: Medicinal uses and conservation. Phcog Rev. 2015;9(18):140-8.

23. Chao Z, Liao J, Liang Z, Huang S, Zhang L, Li J. Cytochrome C oxidase subunit I barcodes provide an efficient tool for Jinqian Baihua She (Bungarus parvus) authentication. Phcog Mag. 2014;10(40):449-57.

24. Owis Al, Abdelwahab NS, Abul-Soad AA. Elicitation of phenolics from the micropropagated endangered medicinal plant Calligonum polygonoides $\mathrm{L}$. (Polygonoaceae). Phcog Mag. 2016;12(Suppl S4):465-70.

25. Coutinho HD, Vasconcellos A, Freire-Pessôa HL, Gadelha CA, Gadelha TS, Almeida-Filho GG. Natural products from the termite Nasutitermes corniger lowers aminoglycoside minimum inhibitory concentrations. Phcog Mag. 2010;6(21):1-4.

26. Tabassum N, Hamdani M. Plants used to treat skin diseases. Phcog Rev. 2014;8(15):52-60

\section{PICTORIAL ABSTRACT}

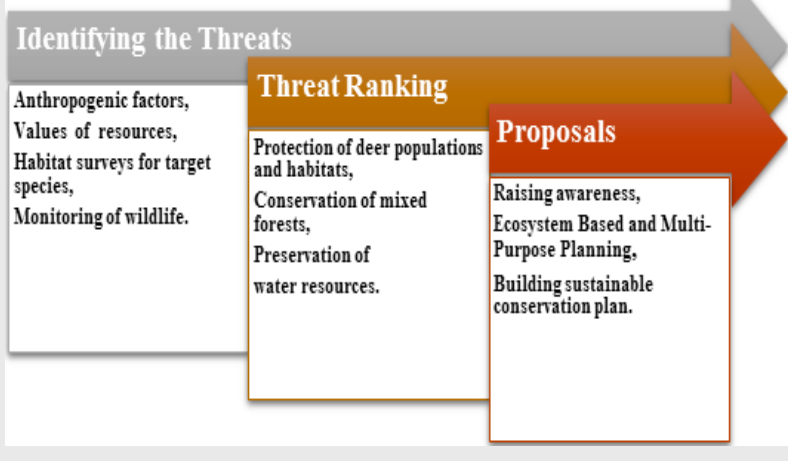

\section{SUMMARY}

- The study determines potential threats and proposing solutions for Elekdag WDA located in Kastamonu.

- Most of threats occurs as a result of human activities.

- Determining the threats and pressures and identification of strategies for threats are important in the management of protected areas.

- True conservation can only be possible by increasing awareness of people about conserving wildlife habitats.

\section{About Authors}

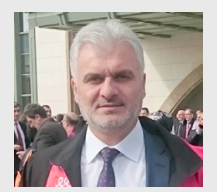

Dr. Ömer Küçük: Professor at Kastamonu University, Dean of Forestry Faculty. He received his MSc and $\mathrm{PhD}$ from Karadeniz Technical University, Turkey. He is focused on forest fire management and wildlife management. He has many international publications, also he is a member of editorial boards on many International Journals. He is guiding many MSc and PhD students.

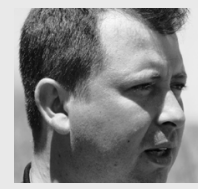

Dr. Kerim Güney: He has been working as Assistant Professor at Botanic department, Forest Engineering Faculty in Kastamonu University. Kerim Güney has many publications on flora, vegetation, biodiversity and medical and aromatic plants.

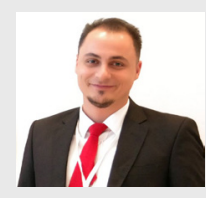

Özkan Evcin: PhD Candidate, Research Assistant at Kastamonu University, Faculty of Forestry. He received his MSc from Kastamonu University, Turkey. He is focused on wildlife ecology and management. He has many national and international publications.

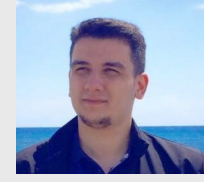

Emre Aktürk: Research Assistant at Kastamonu University, Faculty of Forestry. He received his MSc from Clemson University, South Carolina, USA. He is working about GIS, remote sensing and vegetation ecology.

Cite this article: Küçük Ö, Güney K, Evcin Ö, Aktürk E. Threat Analysis and Proposed Solutions for Elekdag Wildlife Development Area. Indian J of Pharmaceutical Education and Research. 2017;51(3)Suppl:S398-402. 